\title{
Development of a greenhouse-based inoculation protocol for the fungus Colletotrichum cereale pathogenic to annual bluegrass (Poa annua)
}

Lisa A. Beirn, Ruying Wang, Bruce B. Clarke, Jo Anne Crouch

The fungus Colletotrichum cereale incites anthracnose disease on Poa annua (annual bluegrass) turfgrass. Anthracnose disease is geographically widespread throughout the world and highly destructive to cool-season turfgrasses, with infections by $C$. cereale resulting in extensive turf loss. Comprehensive research aimed at controlling turfgrass anthracnose has been performed in the field, but knowledge of the causal organism and its basic biology is still needed. In particular, the lack of a reliable greenhouse-based inoculation protocol performed under controlled environmental conditions is an obstacle to the study of $C$. cereale and anthracnose disease. Our objective was to develop a consistent and reproducible inoculation protocol for the two major genetic lineages of $C$. cereale. By adapting previously successful field-based protocols and combining with components of existing inoculation procedures, the method we developed consistently produced $C$. cereale infection on two susceptible $P$. annua biotypes. Approximately 7 to 10 days postinoculation, plants exhibited chlorosis and thinning consistent with anthracnose disease symptomology. Morphological inspection of inoculated plants revealed visual signs of the fungus (appressoria and acervuli), although acervuli were not always present. After stringent surface sterilization of inoculated host tissue, $C$. cereale was consistently reisolated from symptomatic tissue. Real-time PCR detection analysis based on the Apn2 marker confirmed the presence of the pathogen in host tissue, with both lineages of $C$. cereale detected from all inoculated plants. When a humidifier was not used, no infection developed for any biotypes or fungal isolates tested. The inoculation protocol described here marks significant progress for in planta studies of $C$. cereale, and will enable scientifically reproducible investigations of the biology, infectivity and lifestyle of this important grass pathogen. 
1 Development of a greenhouse-based inoculation protocol for the fungus Colletotrichum cereale

2 pathogenic to annual bluegrass (Роа аппиа)

3

4 Lisa A. Beirn ${ }^{1}$, Ruying Wang ${ }^{1}$, Bruce B. Clarke ${ }^{1}$, and Jo Anne Crouch ${ }^{2}$

$6 \quad{ }^{1}$ Department of Plant Biology and Pathology, Rutgers University, New Brunswick, NJ, USA

$7 \quad{ }^{2}$ Systematic Mycology and Microbiology, USDA-ARS, Beltsville, MD, U.S.A.

9 Corresponding Author: Jo Anne Crouch, 301-504-6922, JoAnne.Crouch@ars.usda.gov

10 Abstract

11 The fungus Colletotrichum cereale incites anthracnose disease on Poa annua (annual bluegrass)

12 turfgrass. Anthracnose disease is geographically widespread throughout the world and highly

13 destructive to cool-season turfgrasses, with infections by C. cereale resulting in extensive turf

14 loss. Comprehensive research aimed at controlling turfgrass anthracnose has been performed in

15 the field, but knowledge of the causal organism and its basic biology is still needed. In

16 particular, the lack of a reliable greenhouse-based inoculation protocol performed under

17 controlled environmental conditions is an obstacle to the study of C. cereale and anthracnose

18 disease. Our objective was to develop a consistent and reproducible inoculation protocol for the

19 two major genetic lineages of C. cereale. By adapting previously successful field-based

20 protocols and combining with components of existing inoculation procedures, the method we

21 developed consistently produced C. cereale infection on two susceptible P. annua biotypes.

22 Approximately 7 to 10 days post-inoculation, plants exhibited chlorosis and thinning consistent

23 with anthracnose disease symptomology. Morphological inspection of inoculated plants 
24 revealed visual signs of the fungus (appressoria and acervuli), although acervuli were not always 25 present. After stringent surface sterilization of inoculated host tissue, C. cereale was consistently

26 re-isolated from symptomatic tissue. Real-time PCR detection analysis based on the Apn2

27 marker confirmed the presence of the pathogen in host tissue, with both lineages of C. cereale

28 detected from all inoculated plants. When a humidifier was not used, no infection developed for

29 any biotypes or fungal isolates tested. The inoculation protocol described here marks significant

30 progress for in planta studies of C. cereale, and will enable scientifically reproducible

31 investigations of the biology, infectivity and lifestyle of this important grass pathogen.

\section{Introduction}

Anthracnose, caused by the ascomycete fungus Colletotrichum cereale Manns sensu lato

34 Crouch, Clarke, and Hillman (Crouch et al. 2006), is a destructive disease of Poa annua L. f.

35 reptans [Hauskins] T. Koyama (annual bluegrass) putting green turf. The disease has increased

36 in frequency and severity over the past decade, leading to the development of environmentally

37 sound best management practices that have reduced anthracnose severity on golf course putting

38 greens in North America (Murphy et al., 2008). While improved anthracnose disease control

39 measures are leading to reduced losses for many turfgrass management professionals (Murphy et

40 al. 2008), essential knowledge about the biology and infectivity of this pathogen is still lacking.

41 An understanding of virulence, host-pathogen interactions, the infection process, and pathogen

42 genetics is vital to facilitate disease prediction, improve management practices, and enhance

43 cultivar resistance. However, such advancements have been limited by the lack of a reliable,

44 greenhouse-based experimental inoculation protocol, preventing the study of turfgrass

45 anthracnose in a controlled and reproducible environment (Murphy et al., 2008). 
Field inoculations of $P$. annua putting green turf with $C$. cereale are routinely performed

47 (e.g. Inguagiato Murphy \& Clarke, 2008, 2009; Beirn et al. 2015). Briefly, the asexual spores

48 (conidia) of C. cereale are harvested from axenic cultures, normalized to $5.0 \times 10^{-4}$ conidia $\mathrm{mL}^{-1}$,

49 and sprayed onto turf using a backpack sprayer approximately three hours before sundown

50 during hot, humid weather when conditions are conductive for anthracnose disease (Inguagiato,

51 Murphy \& Clarke, 2008). This process is typically repeated for 3 to 5 successive days, with

52 inoculated plants covered with polyethylene sheets overnight to prevent desiccation of conidia

53 (Inguagiato, Murphy \& Clarke, 2008). Early reports in the literature describe a similar procedure

54 used for greenhouse inoculations of $P$. annua plants with spore solutions of C. cereale (Bolton \&

55 Cordukes 1981; Vargas \& Detweiler, 1985; Vargas, Danneberger \& Jones, 1993), but consistent

56 infection using these methods have been difficult to reproduce (Murphy et al. 2008). Inoculation

57 of $P$. annua plants with agar plugs colonized by the pathogen have also produced inconsistent

58 disease symptoms (Backman, Landschoot \& Huff, 1999). Detached leaf assays were used to

59 study the infection of Agrostis stolonifera L. (creeping bentgrass) grass plants by C. cereale

60 (Khan and Hsiang 2003). However, the use of detached leaf assays only provides information

61 about the process of substrate utilization, and is unlikely to mirror the host-pathogen interaction

62 that take place between C. cereale and intact grass plants. Colletotrichum pathogens of grasses

63 utilize a hemibiotrophic strategy to colonize hosts, which is characterized by an initial stage of

64 quiescent biotrophy, followed by a shift to necrotrophic colonization and degradation of host

65 tissue, resulting in unique waves of differential gene expression taking place during each phase

66 (Crouch \& Beirn 2009; O’Connell et al. 2012; Crouch et al. 2014). Gene expression studies of

67 the hemibiotrophic infection strategy have revealed significantly different expression profiles in 
attached and detached Arabidopsis leaves when inoculated with C. higginsianum (Liu et al. 2007), thus detached leaf assays may not accurately reflect what is occurring in planta. Natural populations of $C$. cereale are diverse, with ten distinct populations described from DNA sequence analysis using four markers (Crouch et al. 2009b). Moreover, the species has been subdivided into two primary genetic lineages, termed clade A and B (Crouch, Clarke \& Hillman, 2006). Although divergent, these two major clades are connected through gene flow sufficient to maintain the lineages as a single phylogenetic species (Crouch et al., 2008; Crouch, Clarke \& Hillman, 2009, 2009b). Among isolates of $C$. cereale collected from P. annua and $A$. stolonifera putting greens, the distribution of clades A and B is strongly influenced by geographic and host origin (Beirn, Crouch \& Clarke, 2014). Clade A predominates in the southern U.S., regardless of host (Beirn, Crouch \& Clarke, 2014). In contrast, clade A and clade $\mathrm{B}$ isolates have been found in equal frequencies and both lineages can occur on both hosts in the northern U.S.; however, clade A isolates are found more frequently on P. annua and clade B is more common on A. stolonifera (Beirn, Clarke \& Crouch, 2014). It is currently not known whether these population-scale differences affect infectivity or the ability of the pathogen to colonize different host species, but this association of specific genotypes in natural populations could explain the difficulties surrounding the development of a consistent, reproducible inoculation protocol for C. cereale. The development of a reliable, greenhouse-based inoculation protocol for both C. cereale lineages would allow researchers to explore many unanswered questions about the disease cycle, host-pathogen interactions, and biology of C. cereale in a controlled environment. Therefore, the objective of this study was to develop a greenhouse-based inoculation protocol for both $C$. 
90 cereale genetic lineages by adapting and modifying existing spore solution inoculation methods

91 and field-based protocols.

92 Materials and Methods

93 Turfgrass Hosts

94 Pоа аппиа biotypes 98226,99112 and 9712 were seeded $(0.2 \mathrm{~g}$ per pot) in $10 \mathrm{~cm}$ pots

95 filled with Fafard Canadian Grow Mix 2 (Agawam, MA). All biotypes were originally collected

96 as seed from putting greens in the U.S. Biotypes were selected based on their susceptibility to

97 anthracnose disease in turfgrass research plots at the Pennsylvania State University in State

98 College, Pennsylvania (Dave Huff, personal communication, November 7, 2011). Prior to

99 inoculation, each biotype was tested for the presence of endophytic fungi. Colletotrichum

100 cereale can survive asymptomatically in host tissue (Crouch et al., 2009b), thus the presence of

101 endophytic C. cereale strains could confound real-time PCR results. In addition, each biotype

102 was screened for existing mycorrhizal associations. For endophyte testing, $2 \mathrm{~g}$ of leaf tissue was

103 randomly selected from $10 \mathrm{~cm}$ pots, trimmed to fit inside a $25 \mathrm{~mL}$ polypropylene tube (BD

104 Falcon, Bedford, MA), then washed for $2 \mathrm{~min}$ in $70 \% \mathrm{EtOH}, 2 \mathrm{~min}$ in $10 \%$ commercial $\mathrm{NaClO}$,

105 three rinses for $1 \mathrm{~min}$ in sterile $\mathrm{dH}_{2} \mathrm{O}$, and $10 \mathrm{~s}$ in $95 \% \mathrm{EtOH}$. Surface sterilized tissue was

106 plated onto malt extract agar (MEA, Fisher Scientific, Pittsburgh, PA), and incubated at room

107 temperature under continuous light for 3 weeks. For mycorrhizae testing, $0.5 \mathrm{~g}$ of $P$. annua roots

108 were selected at random from established plants. Harvested roots were washed with $\mathrm{dH}_{2} \mathrm{O}$ and

109 stained for mycorrhizae following a modified procedure of Phillips and Hayman (1970). Briefly,

$1101.5 \mathrm{~cm}$ root segments were heated in $10 \% \mathrm{KOH}$ for $1 \mathrm{~h}$ at $90^{\circ} \mathrm{C}$. Cleared root segments were

111 rinsed in tap water for $2 \mathrm{~min}$, heated for $1 \mathrm{~h}$ in $20 \% \mathrm{HCl}$, followed by a final heating in $0.1 \%$

112 trypan blue (Roche Applied Science, Indianapolis, IN) for $30 \mathrm{~min}$. Stained roots were mounted 
113 on microscope slides and visualized using an Olympus BX41 clinical 71 microscope (New York

114 / New Jersey Scientific, Middlebush, NJ).

115 Fungal Isolates

116 Two isolates of C. cereale were used in this study. Isolate TCGC5-63 (clade A) was

117 collected from P. annua in 2002 from a golf course putting green in Temecula, CA, whereas

118 isolate HF217CS (clade B) was collected from P. апnиa in 2012 from turfgrass research plots in

119 North Brunswick, NJ. Fungal specimens are deposited in Centraalbureau voor Schimmelcultures

120 (Utrecht, The Netherlands). Prior to inoculation, isolates were removed from $-80^{\circ} \mathrm{C}$ storage,

121 where they were maintained as desiccated conidia on silica gel in $1 \mathrm{~mL}$ cryogenic tubes (Fisher

122 Scientific, Pittsburgh, PA), and placed on potato dextrose agar (PDA, Fisher Scientific,

123 Pittsburgh, PA) under continuous light at room temperature. After fungal growth covered the

124 PDA plates ( 8-10 days), $10 \mathrm{~mL}$ of sterile $\mathrm{dH}_{2} \mathrm{O}$ was poured onto the plate and fungal mycelia

125 and spores were gently removed by scraping with a sterile glass rod. A sterile inoculation loop

126 was used to streak the fungal suspension onto a fresh PDA plate. Streaked plates were not sealed

127 with parafilm and were placed under direct light at room temperature to encourage sporulation

128 ( 3-4 days).

129 Inoculation Protocol

130 All P. апnиa biotypes were inoculated with each C. cereale isolate in separate treatments,

131 with three replications per biotype. The inoculation protocol consisted of a $20 \mathrm{~mL}$ conidial

132 suspension $\left(10^{-6}\right.$ conidia $\left./ \mathrm{mL}\right)$ of C. cereale and $10 \%$ potato dextrose broth (PDB, Fisher

133 Scientific, Pittsburgh, PA). The conidial suspension was sprayed onto the foliage of 8 wk post-

134 emergent $P$. аnnua plants using a hand atomizer. Non-inoculated plants were sprayed with 20

$135 \mathrm{~mL} \mathrm{10 \%} \mathrm{PDB} \mathrm{as} \mathrm{a} \mathrm{control.} \mathrm{Following} \mathrm{inoculation,} \mathrm{plants} \mathrm{were} \mathrm{placed} \mathrm{in} \mathrm{a} \mathrm{custom-made}$ 
136 plexiglass mist chamber inside a growth chamber for $24 \mathrm{~h}$. The plexiglass chamber measured

$13791.5 \mathrm{~cm} \times 63.5 \mathrm{~cm} \times 76.2 \mathrm{~cm}$ and was constructed with $7.9 \mathrm{~mm}$ plexiglass. A humidifier

138 (Herrmidifier, Phoenix, AZ) atomized water into water vapor, providing a source of moisture in

139 the chamber. The humidifier ran for a duration of $1 \mathrm{~h}$ every $2 \mathrm{~h}$. Following incubation, plants

140 were removed from the plexiglass chamber and remained in the growth chamber under

141 conditions of $12 \mathrm{~h}$ daylight $\left(500 \mu \mathrm{E} \mathrm{m}^{-2} \mathrm{~s}^{-1}\right), 80 \% \mathrm{RH}, 30^{\circ} \mathrm{C}$ day, and $26^{\circ} \mathrm{C}$ night until symptom

142 development ( 7 to 10 days). All plants were watered every other day at the base to avoid

143 wetting inoculated foliage during the course of the experiments. The experiment was replicated

144 twice under the same conditions described above and included negative controls. To test the

145 effects of moisture and plant growth medium on the ability of $C$. cereale to infect $P$. annua, the

146 experiment was also repeated under the same growth chamber conditions two additional times,

147 with variations in moisture and plant growth substrate. In one experiment, inoculated plants

148 were seeded in Grow Mix 2, but no humidifier was used during the inoculation period. In the

149 other experiment, plants were seeded in sand and inoculated and moisture was supplied as

150 previously described.

151 Confirmation of Infection

152 Infection was confirmed in three ways: 1). inoculated plants were visually inspected for

153 signs of the fungus (appressoria and acervuli), 2). C. cereale was re-isolated from inoculated

154 tissue after symptom development, and 3). inoculated plants were tested for the presence of $C$.

155 cereale using real-time PCR, C. cereale clade-specific assays developed using the Apn2 marker

156 (Beirn, Clarke \& Crouch 2014). This assay confirms to the Minimum Information for

157 Publication of Quantitative Real-Time PCR Experiments guideline; complete details describing

158 the assay can be found in Beirn, Clarke \& Crouch (2014). For pathogen isolations and real-time 
159 PCR, plant tissue was surfaced sterilized prior to plating or DNA analysis with $10 \%$ commercial

$160 \mathrm{NaClO}$ for $2 \mathrm{~min}, 70 \% \mathrm{EtOH}$ for $2 \mathrm{~min}$, rinsed in sterile $\mathrm{dH}_{2} \mathrm{O}$, and allowed to dry in a sterile

161 hood. Half of the dried tissue was plated onto PDA, while the remaining tissue was used for

162 real-time PCR analysis.

163 DNA was extracted from the remaining tissue using the OmniPrep DNA Extraction Kit

164 (G-BioSciences, St. Louis, MO) and a modified manufacturer's protocol. Briefly, $0.5 \mathrm{~g}$ of plant

165 tissue was placed in a $2 \mathrm{~mL}$ microcentrifuge tube with eight $2.5 \mathrm{~mm}$ glass beads (BioSpec

166 Products, Barletsville, OK) and beat in a BioSpec bead-beater (Barletsville, OK) on the medium

167 setting for six minutes. The manufacturer's protocol was followed for the remaining steps.

168 Real-time PCR reactions were performed as previously described (Beirn, Clarke \& Crouch 2014)

169 using a Cepheid SmartCycler (Cepheid, Sunnyvale, CA) in $25 \mu$ l Cepheid tubes. Briefly,

170 Cepheid's Smartmix HM lyophilized PCR master mix was used for all reactions with a final

171 probe concentration of $2 \mu \mathrm{M}$ and primer concentration of $20 \mu \mathrm{M}$. Cycling conditions were as

172 follows: initial denaturation at $95^{\circ} \mathrm{C}$ for $120 \mathrm{~s}$, followed by 45 cycles of $95^{\circ} \mathrm{C}$ for $5 \mathrm{~s}, 60^{\circ} \mathrm{C}$

173 anneal for $30 \mathrm{~s}$, and $72^{\circ} \mathrm{C}$ extension for $1 \mathrm{~s}$. Samples were considered positive if the fluorescent

174 threshold (30) was crossed prior to cycle 40 and negative if samples produced cycle threshold

$175\left(\mathrm{C}_{\mathrm{T}}\right)$ values equal to zero.

176 Results

177 Mycorrhizae and Endophyte Testing

178 No visual signs of endophytic fungi or mycorrhizae were found in any of the P. annua

179 biotypes used in this study.

180 Inoculation results

181 Appressoria formation was observed on P. апnиa biotypes 99112 and $98226 \sim 24$ hours 
182 after inoculation with both C. cereale isolates on plants grown in potting mix and sand (Fig. 1A).

183 Appressoria were randomly distributed on leaf surfaces and were dark brown/black and rounded

184 or lobed, measuring $9-10 \mu \mathrm{m}$ by $6-9.5 \mu \mathrm{m}$. Disease symptoms were not observed until 6 to 9

185 days after appressoria formation on P. annua biotypes 99112 and 98226, and were similar for

186 plants seeded in potting mix or sand. Although leaf lesions were never present, plants inoculated

187 with C. cereale isolate TCGC5-63 or isolate HF217CS appeared chlorotic when compared to

188 uninoculated controls (Fig. 1B). Acervuli with diagnostic black setae were only present on

189 plants inoculated with C. cereale isolate TCGC5-63 (Fig. 1C). Numerous falcate, hyaline

190 conidia were found in conjunction with acervuli. P. апnиa biotype 9712 never developed any

191 leaf symptoms or signs and was negative for all tests for the presence of C. cereale. Negative

192 controls did not develop any disease symptoms, and did not exhibit any signs of fungal

193 colonization.

194 Both isolates of C. cereale were re-isolated from symptomatic plant tissues on PDA.

195 Mycelium was white at first, then turning slightly gray with age (Fig. 1D). Numerous acervuli

196 were formed on the agar surface, forming in the older parts of the colony first. Conidia appeared

197 orange colored in mass and measurements conformed to those reported for C. cereale (Crouch et

198 al. 2006). Cultures of C. cereale were recovered from all symptomatic plants, regardless of

199 whether they were seeded in potting mix or sand. Control plants generated no isolates of $C$.

200 cereale upon culturing.

201 No infection was present in inoculated plants where the humidifier was not used.

\section{Real-time PCR confirmation}

203 Leaf tissue samples were taken from all plants to either confirm infection or, in the case

204 of the controls, to verify the absence of infection. Real-time PCR confirmed infection for both 
C. cereale isolates HF217CS and TCGC5-63 on P. annua biotypes 99112 and 98226, with

206 average $C_{T}$ values of 32.90 and 32.04, respectively. Control plants and inoculated biotype 9712

207 generated $\mathrm{C}_{\mathrm{T}}$ values of 0.00 . DNA sequences of the ITS region amplified from the isolated fungi

208 matched C. cereale isolates in the GenBank database with 100\% similarity (data not shown).

\section{Discussion}

210 The primary objective of this study was to develop a repeatable inoculation protocol for

211 the two C. cereale genetic lineages commonly found on P. annua. Two biotypes of $P$. annua

212 were successfully inoculated with a clade A and clade B isolate of C. cereale, representing the

213 first documented occurrence of a successful inoculation protocol for both genetic lineages of $C$.

214 cereale on the same plant biotype. The methods developed here are similar to methods reported

215 in earlier literature (e.g. Bolton and Cordukes, 1981; Vargas \& Detweiler, 1985; Vargas,

216 Danneberger \& Jones, 1993), but, unlike these studies, lesions were never observed on

217 inoculated plant material in our study. However, inoculated plants did appear visibly chlorotic

218 and thinned, C. cereale was successfully isolated from symptomatic hosts, and real-time PCR

219 detected the presence of the fungus after rigorous surface sterilization. These findings reflect

220 what was recently observed in the centipedegrass-anthracnose pathosystem, where inoculated

221 plants appeared chlorotic and, over time, necrotic, with no acervuli present (Crouch \& Tomaso-

222 Peterson, 2012). Molecular detection methods, in combination with Koch's postulates, also

223 confirmed pathogenicity in this system (Crouch \& Tomaso-Peterson, 2012).

224 One $P$. annua biotype, 9712, never developed infection with C. cereale, despite

225 displaying susceptibility in the field. Early research with C. cereale suggested the presence of

226 multiple races in cereal plants, as certain strains of the fungus were not able to infect all cultivars

227 of cereal crops tested (Sanford, 1935; Bruehl, 1948; Bell, 1949), though race genotyping has 
228

229

230

231

232

233

234

235

236

237

never been performed. Cultivar-race specificity is known to occur in $C$. lindemuthianum, the causal agent of bean anthracnose (Barrus, 1911), thus the presence of multiple races in C. cereale would not be surprising. Though additional data is required to test this hypothesis, this observation may explain why $C$. cereale inoculations have been difficult to reproduce in previous field and greenhouse studies. In addition, the lack of acervuli produced in planta in many studies may also be a contributing factor; some isolates used in inoculations may have little affinity for forming acervuli in planta, making it difficult to verify the presence of the fungus. Without molecular technologies and this diagnostic feature, confirming the presence of C. cereale is dependent on re-isolating the fungus, a task that can be difficult and time consuming. Our real-time PCR probes (Beirn, Clarke \& Crouch 2014) provide a reliable method for testing the presence of $C$. cereale in planta, allowing for quick disease diagnosis, pathogen quantification, and lineage genotyping.

Our data shows that moisture on the leaf surface over an extended period is required for establishing C. cereale infection in a controlled setting. This supports the observations of Vargas, Danneberger and Jones (1993), where increasing leaf wetness from 12 to $72 \mathrm{~h}$ drastically increased the percent of $C$. cereale infections on inoculated plants. Extended periods of leaf wetness also appears to be a requirement for other grass infecting Colletotrichum species. Inoculation protocols developed for C. eremochloae, the causal agent of centipedegrass anthracnose, and C. navitas, the causal agent of anthracnose disease of switchgrass, both describe placing plants in plastic containers or bags following spraying with conidial solutions (Crouch and Tomaso-Peterson, 2012; Crouch et al., 2009a). This practice not only increases humidity, but also encourages water droplet formation within the container, many of which often drip back to the leaf surface. Without excess moisture, conidia may face desiccation before they 
251 are able to germinate, thereby preventing infection. While we did not evaluate whether bagging

252 plants inoculated with C. cereale results in infection similar to that obtained with using the

253 humidity chamber, the success of this technique with other grass-infecting Colletotrichum

254 species suggests that this may be a viable option for those seeking to study C. cereale infection

255 when a humidity chamber is not available.

256 The development of a rapid and reliable, greenhouse-based inoculation protocol marks a 257 significant milestone for advancing in planta studies of C. cereale. This tool will serve as a

258 foundation for investigating the biology and infectivity of this important pathogen under

259 controlled environmental conditions. Further, specific questions about the infectivity of both $C$.

260 cereale lineages as well as rapid screening of turfgrass germplasm to speed the development of

261 cultivars with resistance to anthracnose can now be addressed.

262 Acknowledgements

263 We thank Dave Huff for supplying seed of $P$. апnua biotypes, Mark Peacos for support building

264 the misting chamber, and Joe Florentine and Jeff Akers for assistance with the growth chamber.

265 References

266 Backman PA, Landschoot PJ, Huff DR. 1999. Variation in pathogenicity, morphology, and

267 RAPD marker profiles in Colletotrichum graminicola from turfgrasses. Crop Science 39:11292681135.

269

270 Barrus MF. 1911. Variation in varieties of beans in their susceptibility to anthracnose.

271 Phytopathology 1:190-195.

272 
273 Beirn LA, Clarke BB, Crouch JA. 2014. Influence of host and geographic locale on the

274 distribution of Colletotrichum cereale lineages. PLoS ONE 9(5): e97706.

275 doi:10.1371/journal.pone.0097706.

276

277 Beirn LA, Schmid CJ, Hempfling JW, Murphy JA, Clarke BB, Crouch JA. 2015. Metagenomic 278 analysis of the rhizosphere microbial community in Poa annua turf across fertility treatments 279 reveals unexpected and widespread diversity. In review: Microbial Ecology: in review. 280

281 Bell FH. 1949. Anthracnose of cereals and other grasses. D. Phil. Thesis, The Ohio State 282 University.

283

284 Bolton AT, Cordukes WE. 1981. Resistance to Colletotrichum graminicola in strains of Poa 285 anпua and reaction of other turfgrasses. Canadian Journal of Plant Pathology 3:94-96. 286

287 Bruehl GW. 1948. Anthracnose of cereals and grasses. Phytopathology 38:3-4. 288

289 Crouch JA, Beirn LA. 2009. Anthracnose disease of cereals and grasses. Fungal Diversity $290 \quad 39: 19-44$.

291

292 Crouch JA, Beirn LA, Cortese LM, Bonos SA, Clarke BB. 2009a. Anthracnose disease of 293 switchgrass caused by the novel fungal species Colletotrichum navitas. Mycological Research 294 113:1411-1421. 295 
296 Crouch JA, Clarke BB, Hillman BI. 2006. Unraveling evolutionary relationships among

297 divergent lineages of Colletotrichum causing anthracnose disease in turfgrass and corn.

298 Phytopathology 96:46-60.

299

300 Crouch JA, Clarke BB, Hillman BI. 2009. What is the value of ITS sequence data in

301 Colletotrichum systematics and species diagnosis? A case study using the falcate-spored

302 graminicolous Colletotrichum group. Mycologia 101:648-656.

303

304 Crouch JA, Glasheen BM, Giunta MA, Clarke BB, Hillman BI. 2008. The evolution of

305 transposon repeat-induced point mutation in the genome of Colletotrichum cereale: reconciling

306 sex, recombination, and homoplasy in an "asexual" pathogen. Fungal Genetics and Biology

$307 \quad 45: 190-206$.

308

309 Crouch JA, O’Connell R, Gan P, Buiate E, Torres MF, Beirn L, Shirasu K, Vaillancourt L.

310 2014. The genomics of Colletotrichum. In: Genomics of plant-associated fungi: Monocot

311 pathogens. Berlin: Springer Verlag, 69-102.

312

313 Crouch JA, Tomaso-Peterson M. 2012. Anthracnose disease of centipedegrass turf caused by

314 Colletotrichum eremochloae, a new fungal species closely related to Colletotrichum sublineola.

315 Mycologia 104:1085-1096.

316 
317 Crouch JA, Tredway LP, Clarke BB, Hillman BI. 2009b. Phylogenetic and population genetic

318 divergence correspond with habitat for the pathogen Colletotrichum cereale and allied taxa

319 across diverse grass communities. Molecular Ecology 18:123-135.

320

321 Inguagiato JC, Murphy JA, Clarke BB. 2008. Anthracnose severity on annual bluegrass

322 influenced by nitrogen fertilization, growth regulators, and verticutting. Crop Science 48: 15953231607.

324

325 Inguagiato JC, Murphy JA, Clarke BB. 2009. Anthracnose disease and annual bluegrass putting

326 green performance affected by mowing practices and lightweight rolling. Crop Science 49:14543271462.

328

329 Khan A, Hsiang T. 2003. The infection process of Colletotrichum graminicola and relative 330 aggressiveness on four turfgrass species. Canadian Journal of Microbiology 49: 433-442.

332 Liu G, Kennedy R, Greenshields DL, Peng G, Forseille L, Selvaraj G, Wei Y. 2007. Detached 333 and attached Arabidopsis leaf assays reveal distinctive defense responses against hemibiotrophic 334 Colletotrichum spp. Molecular Plant Microbe Interactions 20:1308-1319.

335

336 Murphy JA, Wong FP, Tredway LP, Crouch JA, Inguagiato JC, Clarke BB, Hsiang T, Rossi, F.

337 2008. Best management practices for turfgrass anthracnose disease. Golf Course Management $338 \quad 76: 93-104$. 
340 O'Connell RJ, Thon MR, Hacquard S, ver Loren van Themaat E, Amyotte S, Kleemann J,

341 Torres-Quintero M, Damm U, Buiate E, Epstein L, Aklan N, Altmuller J, Alvarado-Balderrama

342 L, Bauser C, Becker C, Birren BW, Chen Z, Crouch JA, Duvick J, Farman M, Gan P, Heiman D,

343 Henrissat B, Howard RJ, Kabbage M, Koch C, Kubo Y, Law A, Lebrun MH, Lee YH, Miyara I,

344 Moore N, Neumann U, Panaccione DG, Panstruga R, Place M, Proctor RH, Prusky D, Rech G,

345 Reinhardt R, Rollins JA, Rounsley S, Schardl C, Schwartz DC, Shenoy N, Shirasu K, Stuber K,

346 Sukno SA, Sweigard JA, Takano Y, Takahara H, van der Does HC, Voll L, Will I, Young S,

347 Zeng Q, Zhang J, Zhou S, Dickman MB, Schulze-Lefert P, Ma LJ, Vaillancourt LJ. 2012.

348 Lifestyle transitions in plant pathogenic Colletotrichum fungi deciphered by genome and

349 transcriptome analyses. Nature Genetics 44:1060-1065.

350

351 Phillips JM, Haymanm DS. 1970. Improved procedures for clearing roots and staining parasitic 352 and vesicular-arbuscular mycorrhizal fungi for rapid assessment of infection. Transactions of 353 the British Mycological Society 55:158-161.

354

355 Sanford GB. 1935. Colletotrichum graminicola (Ces.) Wils.as a parasite of the stem and root 356 tissues of Avena sativa. Scientific Agriculture 15:370-376.

357

358 Vargas JM, Detweiler R. 1985. Anthracnose of Poa annua: the pathogenicity of Colletotrichum 359 graminicola. International Turfgrass Society Research Journal 5:637-640. 
361 Vargas JM, Danneberger TK, Jones AL. 1993. Effects of temperature, leaf wetness duration, and

362 inoculum concentration on infection of annual bluegrass by Colletotrichum graminicola.

363 International Turfgrass Society Research Journal 7:324-328.

364

365

366

367

368

369 


\section{1}

Photographs of Poa annua plants inoculated with Colletotrichum cereale

Photographs of Poa annua plants inoculated with Colletotrichum cereale. A. Numerous appressoria of $C$. cereale on inoculated leaf, B. P. annua biotype 98226 uninoculated control on the left, compared to plants of the same biotype inoculated with $C$. cereale on the right, $\mathrm{C}$. C. cereale isolate TCGC5-63 acervulus on inoculated plant tissue, and D. C. cereale culture TCGC5-63 re-isolated from inoculated tissue.
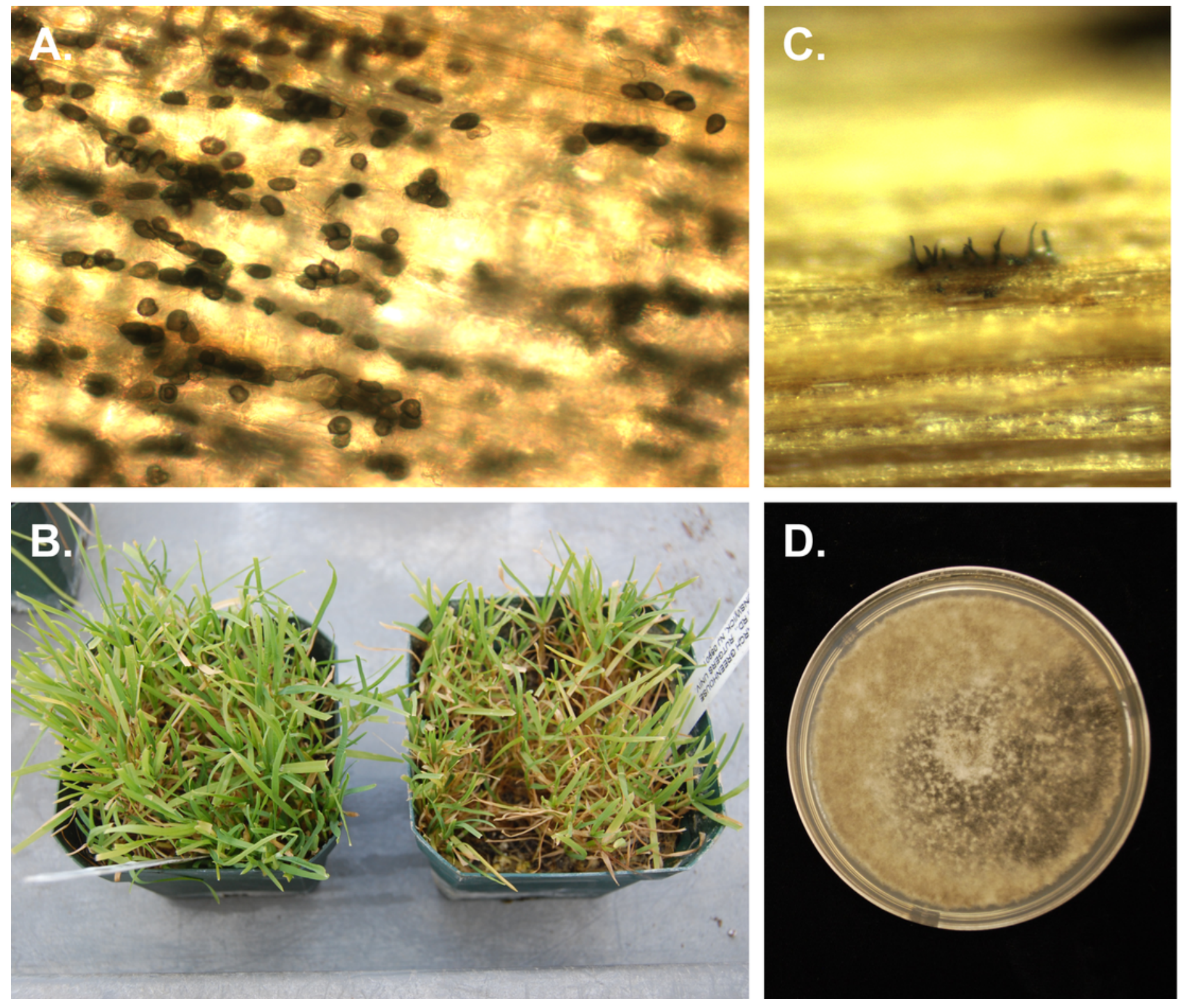